\title{
A HAGYOMÁNYOS ÉS A RUGALMAS GYÁRTÓRENDSZEREK LOGISZTIKAI ASPEKTUSAI
}

\author{
Fükő László \\ PhD hallgató, Miskolci Egyetem, Logisztikai Intézet \\ 3515 Miskolc, Miskolc-Egyetemváros, e-mail: laszlo.fuko@hotmail.com \\ Illés Béla \\ egyetemi tanár, Miskolci Egyetem, Logisztikai Intézet \\ 3515 Miskolc, Miskolc-Egyetemváros, e-mail: altilles@uni-miskolc.hu \\ Wágner György \\ mesteroktató, Miskolci Egyetem, Informatikai Intézet \\ 3515 Miskolc, Miskolc-Egyetemváros, e-mail: wagner@iit.uni-miskolc.hu
}

\begin{abstract}
Absztrakt
Mai változó világunkban egyre nagyobb szerepet kap a vevői vásárlási szokások megváltozása következtében fellépö igény a kis gyártási sorozatban elöállitott vagy éppen egyedi termékek iránt. Ezeknek a termékeknek a gyártása során elvárás a nagyfokú rugalmasság, a hatékonyság (alacsony költségek, rövid átfutási idők) és mindemellett a magas minöség. A rugalmas gyártórendszer logisztikai paraméterei: Rövid átfutási idők, Alacsony összköltség, Magas minőség. A hagyományos tömeggyártási rendszereket többnyire az jellemzi, hogy nagyobb gyártási sorozatokra vannak optimalizálva. A nagyobb gyártási sorozatok elösegithetik az automatizálást, illetve csökkenthetnek olyan költségeket (átállási veszteségek - alapanyag csere gyártósoron, gépek átállitása, átállások után elvégzendö minöségbiztositási tevékenységek, stb.) amelyek kisebb sorozatnagyságnál gyakrabban lépnek fel. A rugalmas gyártási rendszerek ezzel szemben arra vannak felkészitve, hogy a vevői rendelések és az eladási mennyiségek nem, vagy csak nagyon alacsony elörejelzési pontossággal jelezhetök elöre így a jelentkezö vevöi igényekre a lehetö legrövidebb idö alatt reagálhassunk. A rendszer tehetetlenségét minimalizálni kell. Ezért meg kell teremteni a gyors és gyakori átállások, típusváltások lehetöségét alacsony veszteségek mellett. Le kell csökkentenünk a gyártási folyamat átfutási idejét és a sorozatnagyságot. A cikk a vázolt tématerületek aspektusait tárja fel.
\end{abstract}

Kulcsszavak: rugalmas gyártórendszer, logisztika, hagyományos gyártórendszer

\begin{abstract}
In today's changing world, demand for small-series or customized products due to changing customer purchasing patterns is becoming increasingly important. The production of these products requires high flexibility, efficiency (low cost, short lead times) and high quality. Logistic parameters of a flexible production system: -Short lead times, -Low total cost, -High quality. The traditional mass production systems are usually characterized on the way that they are optimized for larger production runs. Larger production batches can facilitate automation and reduce costs (changeover losses - raw material replacement on a production line, machine setting, quality assurance activities after machine setting, etc.) that occur more frequently at smaller batch sizes. On the other hand, flexible production systems are prepared to produce customer orders and sales quantities with no or low forecasting accuracy, so that
\end{abstract}


we can respond to customer needs in the shortest possible time. System inertia should be minimized. Therefore, it is necessary to create the possibility of quick type changes over with low losses. We need to reduce the through put time of the manufacturing process and the batch size. This article explores aspects of the topics outlined.

Keywords: flexible production system, logistics, traditional production system

\section{Bevezetés}

Mai változó világunkban egyre nagyobb szerepet kap a vevői vásárlási szokások megváltozása és az Ipar 4.0 [1] következtében fellépő igény a kis gyártási sorozatban elöállított vagy éppen egyedi termékek iránt [2]. Ezeknek a termékeknek a gyártása során elvárás a nagyfokú rugalmasság, a hatékonyság (alacsony költségek, rövid átfutási idök) és mindemellett a magas minőség [3].

A vevők számára egyre meghatározóbb paraméter a termék elérhetősége, illetve a vásárlási szándék pillanatától kezdve a termék készhez vételéig eltelt idő (lead time) [4].

Az online vásárlások elterjedése az árverseny élesedése mellett a termék elérhetőségét helyezte elötérbe [5]. A vásárlást támogató portálok egy időben számos ajánlatot jelenítenek meg a vásárló keresési paramétereinek megfelelően. Ha egy termék nem elérhető, akkor a döntés egy másik kereskedő elérhető készletére esik [6]. A generált árbevétel tehát nagyban függ a termékek azonnali elérhetőségétől.

A vásárlók többsége azonban elsősorban az árak összehasonlításával a legalacsonyabb költségen szeretne a termékhez jutni. Továbbra is a termék ára az egyik legmeghatározóbb vásárlást befolyásoló paraméter [7]. Ennek megfelelően a termék elöállítási költségeinek minimalizálása az egyik legmeghatározóbb versenyképességi faktor.

\section{Rugalmas gyártórendszerek paraméterezése}

Az online fórumok lehetőséget biztosítanak a vevői visszajelzések sokkal szélesebb körű és gyorsabb felmérésére is. Az egyes termékek vevői értékelése sok vásárló döntését jelentős mértékben befolyásolja [8]. Különösen igaz ez, ha a vevő egy általa még nem ismert terméket, típust vagy márkát keres. Ebből kifolyólag e termékek minősége és az azokkal kapcsolatos értékelések, visszajelzések, kommentárok szintén nagyban befolyásolják a vevői döntéseket.

Ezek a tények segítenek abban, hogy egy rugalmas gyártórendszer esetén meghatározzuk azokat a paramétereket, amelyeket figyelembe kell vennünk annak megtervezésénél [9]. Ezek a következők:

Rövid átfutási idők - A megrendelés beérkezésétől számítva rövid időn belül elérhető legyen a termék a vásárló számára. Különösen fontos ez az egyedi, vevő specifikus termékek esetén. A megrendelés és a leszállítás között maximum néhány nap telhet el. Itt nagy szerepet kap a logisztika a rövid szállítási idők szempontjából.

Alacsony összköltség - az értékteremtési láncot úgy kell optimalizálni, hogy az esetleges tervezési, anyag, gyártási és logisztikai költségek a lehetö legalacsonyabbak legyenek. Itt figyelembe kell vennünk az alapanyag és a késztermék készletezésének és raktározásának költségét is. Az anyag tőke és raktározási költsége szintén fontos logisztikai aspektus. A másik fontos logisztikai szempont a szállítási költségek optimalizálása illetve azok vevőre történő arányos és a speciális vevői igények függvényében esetleg változó nagyságának áthárítása.

Magas minőség - A minőség fogalmának meghatározásához számos definíció áll rendelkezésre, de jelen esetben vegyük alapul azt a gondolatot, hogy a termék az elkészülésének és készre csomagolásának 
pillanatában éri el a legjobb minőségi szintet [10]. Logisztikai szempontból tehát azt kell biztosítanunk, hogy a termék pontosan olyan állapotban kerüljön a vevőhöz amilyen az elkészülése pillanatában volt.

\section{Hagyományos tömeggyártási rendszerek aspektusai}

A hagyományos tömeggyártási rendszereket többnyire az jellemzi, hogy nagyobb gyártási sorozatokra vannak optimalizálva. A nagyobb gyártási sorozatok elösegíthetik az automatizálást, illetve csökkenthetnek olyan költségeket (átállási veszteségek - alapanyag csere gyártósoron, gépek átállítása, átállások után elvégzendő minőségbiztosítási tevékenységek stb.) amelyek kisebb sorozatnagyságnál gyakrabban lépnek fel. A nagy sorozatú gyártás segítheti a gyártási folyamtok biztonságának növelését (pl. magasabb folyamatképességi mutatók vagy statisztikai folyamatszabályzás alkalmazása.)

Mind emellett biztosítani kell azonban, hogy a változó vevői igények és a piacról érkező változások ne okozzák a termelés hektikus ingadozását. Ezért jellemző törekvés a gyártás simítása (leveling) ami egyenletesebb termelés és nagyobb sorozatokat tesz lehetővé. Ehhez azonban szükség van egy megfelelően meghatározott késztermék raktárkészletre ahová a simított gyártásból érkező termékek aktuális vevői megrendelések hiányában eltárolhatóak.

Ez esetben a késztermék készlet megfelelő szintre történő meghatározásához jó minőségű, megbízható adatokra van szükség a várható értékesítések előrejelzése tekintetében [11]. Nem megfelelő előrejelzési pontosság esetén előfordulhat, hogy a készletek magas szinten feltöltésre kerülnek, árbevétel azonban nem generálódik az elvárásoknak megfelelően, mivel nem azokra a termékekre lesz kereslet, amik a raktárkészlet tervezésekor meghatározásra kerültek. Egyfelöl túlkészlet alakul ki a nem keresett termékek tekintetében, míg a keresett, de nem megfelelően készletezett termékek esetében árbevétel vesztéssel számolhatunk, mert a termék nem elérhető a vevő számára.

Az alapanyag és alkatrész beszállítók felé szintén a simított gyártási tervek, az értékesítési előrejelzés és a készletezési ütemterv alapján keretmegrendelések és lehívási ütemtervek készülnek. Az esetleges értékesítési előrejelzésből származó hibák így kihatnak a késztermék oldalra is, mert ha az ütemterveknek megfelelően beszállított alapanyagokból nem készül termék a kereslet hiánya és a telített raktárkészletek miatt, akkor az alkatrészraktárak is előbb vagy utóbb túlkészlettel telítetté válnak, míg az elöre nem jelzett termékekhez szükséges alapanyagokból hiány keletkezik, ami azok gyártását gátolja.

A hagyományos rendszerek esetében tehát fontos az értékesítési előrejelzés pontossága és az arra épülő, megfelelően definiált késztermék készlet.

\section{Rugalmas gyártási rendszerek aspektusai}

A rugalmas gyártási rendszerek ezzel szemben arra vannak felkészítve, hogy a vevői rendelések és az eladási mennyiségek nem, vagy csak nagyon alacsony előrejelzési pontossággal jelezhetők előre így a jelentkező vevői igényekre a lehető legrövidebb idő alatt reagálhassunk.

A rendszer tehetetlenségét minimalizálni kell. Ezért meg kell teremteni a gyors és gyakori átállások, típusváltások lehetőségét alacsony veszteségek mellett. Le kell csökkentenünk a gyártási folyamat átfutási idejét és a sorozatnagyságot. Cél az egydarabos sorozatnagyság és az egydarabos áramlás megvalósítása, a nehezen előre jelezhető késztermék készletek csökkentése vagy teljes megszüntetése. A logisztikai szállítási időket le kell rövidíteni mind késztermék, mind alapanyag oldalon ezzel egy időben a szállítási költségeket csökkenteni kell. Elötérbe kerül a „local for local” alapelv mind az alapanyagok mind a késztermékek tekintetében. Vagyis a gyártást a piacok közelében építjük fel és az alapanyagot közeli beszállítóktól szerezzük be. Így lerövidülnek a szállítási idők, ezzel párhuzamosan a szállítási 
költségek és csökken a reakcióidő. Csökkennek továbbá a raktárkészletek és az úton lévő készletek, ami csökkenti a készletekkel kapcsolatos veszélyeket (pl. fölöslegessé vált, vagy szavatossági időn túli termékek selejtezése) illetve költségeket (tőkeköltség, raktározási költség).

A beérkező előre nehezen kiszámítható megrendelések biztosítása érdekében elegendő alapanyagkészlet kell biztosítani minden rendelhető, gyártásban lévő termékhez. A piaci tapasztalatok alapján ez eltérő méretü lehet. A készlet fogyásvezérelt (pl. min-max vezérlés) készlet legyen, ami gyorsan utántölthető közeli beszállítók által, vagy beszállítók közeli raktáraiból (pl. konszignációs raktár, cross dock) [12].

A késztermék készletek ideális esetben nulla szinten vannak, a gyártás a beérkező megrendelés alapján indul és a legyártott termék azonnal kiszállításra kerül a vevő felé.

Ily módon a késztermék túlkészlet vagy selejtezés veszélye minimális, a tőkeköltség és a raktározási költségek alacsonyak, a szállítási határidők rövidek.

A biztonsági készletek nem a késztermékben, hanem az alapanyag készletben képződnek, amit helyes tervezéssel optimalizálni lehet, de biztosítani kell a gyártás megfelelő rugalmasságát és hatékonyságát a beérkező megrendelések gyors feldolgozása érdekében. Ennek egyik fontos előfeltétele a gyártás belső logisztikájának optimális kialakítása. Hosszú és időigényes logisztikai folyamatok növelik az átfutási időket, a készletszintet és a kezelési költségeket.

\section{5. Összefoglalás}

A dolgozatban bemutatásra került a hagyományos és a rugalmas gyártórendszerek jellemzői, az azokkal kapcsolatos nehézségek és előnyök. Az iparban manapság csak az maradhat a piacon, aki a veszteségeket minimalizálni tudja, így a megnövekedett profitot fejlesztésre, marketingre, stb. tudja fordítani, amivel a versenyképességét javítani tudja.

\section{Köszönetnyilvánítás}

A cikkben ismertetett kutató munka az EFOP-3.6.1-16-2016-00011 jelü „Fiatalodó és Megújuló Egyetem - Innovatív Tudásváros - a Miskolci Egyetem intelligens szakosodást szolgáló intézményi fejlesztése" projekt részeként - a Széchenyi 2020 keretében - az Európai Unió támogatásával, az Európai Szociális Alap társfinanszírozásával valósul meg.

\section{Irodalom}

[1] Prause, G., Atari, S.: On sustainable production networks for industry 4.0 (2017) Entrepreneurship and Sustainability Issues, 4 (4), pp. 421-431. https://doi.org/10.9770/jesi.2017.4.4(2)

[2] Marques, A.F., Alves, A.C., Sousa, J.P.: An approach for integrated design of flexible production systems (2013) Procedia CIRP, 7, pp. 586-591. https://doi.org/10.1016/j.procir.2013.06.037

[3] Gimenez, C., Ventura, E.: Logistics-production, logistics-marketing and external integration: Their impact on performance (2005) International Journal of Operations and Production Management, 25 (1), pp. 20-38. https://doi.org/10.1108/01443570510572222

[4] De Treville, S., Shapiro, R.D., Hameri, A.-P.: From supply chain to demand chain: The role of lead time reduction in improving demand chain performance (2004) Journal of Operations Management, 21 (6), pp. 613-627. https://doi.org/10.1016/j.jom.2003.10.001 
[5] Cao, Y., Ajjan, H., Hong, P.: Post-purchase shipping and customer service experiences in online shopping and their impact on customer satisfaction: An empirical study with comparison (2018) Asia Pacific Journal of Marketing and Logistics, 30 (2), pp. 400-416.

https://doi.org/10.1108/APJML-04-2017-0071

[6] Dadzie, K.Q., Chelariu, C., Winston, E.: Customer service in the internet-enabled logistics supply chain: website design antecedents and loyalty effects (2005) Journal of Business Logistics, 26 (1), pp. 53-78. https://doi.org/10.1002/j.2158-1592.2005.tb00194.x

[7] Song, G., Zhan, Y., Guo, Y.: The effectiveness of online shopping characteristics and logistics service on satisfaction (2016) 2016 13th International Conference on Service Systems and Service Management, ICSSSM 2016

[8] Ramanathan, R., George, J., Ramanathan, U.: The role of logistics in E-commerce transactions: An exploratory study of customer feedback and risk (2014) Supply Chain Strategies, Issues and Models, 9781447153528, pp. 221-233. https://doi.org/10.1007/978-1-4471-5352-8_10

[9] Pellew, Martyn: Agile manufacturing - the role of rapid response logistics (1996) IEE Colloquium (Digest), (74), 3 p. https://doi.org/10.1049/ic:19960500

[10] Cselényi, J., Illés, B.: Logisztikai rendszerek I. (2004), Miskolci Egyetemi Kiadó

[11] Cselényi, J., Illés, B.: Anyagáramlási rendszerek tervezése és irányitása I. (2006), Miskolci Egyetemi Kiadó

[12] Tamás, P., Illés, B.: Raktár-irányitási rendszerek hatékonyságnövelési lehetöségeinek vizsgálata (2016) Müszaki Szemle (EMT) 68: pp. 29-37. 